\title{
ПІДГОТОВКА МАЙБУТНІХ ПЕДАГОГІВ ДО ЗАПОБІГАННЯ СИНДРОМУ ПРОФЕСІЙНОГО ВИГОРАННЯ
}

\author{
Марина Бутиріна \\ кандидат педагогічних наук, доцент, доцент кафедри загальнотехнічних \\ дисциплін, безпеки життєдіяльності та автосправи, \\ ДВНЗ «Донбаський державний педагогічний університет», \\ м. Слов'янськ, Україна \\ ORCID ID 0000-0002-5048-5187 \\ butyrina_mv@ukr.net
}

\section{Володимир Перейма}

кандидат педагогічних наук, доцент, доцент кафедри загальнотехнічних дисциплін, безпеки життєдіяльності та автосправи, ДВНЗ «Донбаський державний педагогічний університет»,

м. Слов'янськ, Україна

ORCID ID 0000-0003-0403-9730

\section{pereima_v@ukr.net}

Анотація. У статті розкрито причини виникнення синдрому професійного вигорання в педагогів, що об'єднані в зовнішні фактори (пов'язані 3 особливостями професійної діяльності) та внутрішні фактори (пов'язані з індивідуальними особливостями людини). Подано ознаки професійного вигорання, що розвиваються впродовж трьох стадій: спочатку зниження самооцінки, згодом самотність та, як наслідок, соматичні розлади організму. Досліджено наслідки професійного вигорання: симптоми, пов'язані 3 фізичним станом людини, із соціальними відносинами та внутрішньоособистісні симптоми. Визначено вплив професійного вигорання на педагогічну діяльність і на безпечну поведінку педагогів. Виділено шляхи подолання професійного вигорання педагогів, що об'єднані в три групи: вплив на фізичне тіло, вплив на емоційний стан, вплив на думки та світосприйняття. Надано рекомендації щодо підготовки майбутніх педагогів до запобігання синдрому професійного вигорання.

Ключові слова: синдром професійного вигорання; педагогічна діяльність; підготовка майбутніх педагогів; стресогенність; зовнішні фактори синдрому професійного вигорання; внутрішні фактори синдрому професійного вигорання.

Постановка проблеми в загальному вигляді. У сучасних умовах реформування освіти одним із першочергових завдань є підготовка спеціалістів у сфері освіти. Сучасний учитель має вирішувати завдання, що вимагають серйозних педагогічних зусиль. Освоєння нового змісту навчальних предметів, нових форм і методів викладання, пошуки ефективних шляхів виховання, реалізація гуманістичної парадигми, необхідність ураховувати дуже швидкі зміни, що відбуваються в суспільстві та інформаційному полі навчального предмета - усе це під силу лише психологічно здоровому, професійно компетентному, творчому вчителю. Професійна діяльність педагогів насичена емоційно навантаженими комунікаціями, пред’являє високі вимоги до 
особистості людини (необхідність постійного саморозвитку, вдосконалення своїх навичок та вмінь) і до іï психічного стану, особливо в умовах великих інформаційних перевантажень i напруженості, викликаних позаурочною, паперовою, монотонною роботою. Це викликає гостру розумову, фізичну i хронічну втому - стрес, який негативно впливає на професійну діяльність людини, може викликати проблеми у сфері комунікацій, негативно позначитися на фізичному і психологічному здоров'ї педагога. Синдром професійного вигорання - найнебезпечніша професійна хвороба педагогів, що є наслідком постійного стресу та має на сьогодні вражаючі масштаби.

Аналіз останніх досліджень і публікацій. У сучасній науковій літературі багато уваги приділяється вивченню синдрому професійного вигорання. Такі автори, як В. Бойко, Н. Водопьянова, О. Волкова, О. Старченкова розглядають цю проблему в психологічному ракурсі. Проблему професійного вигорання в педагогів вивчають у своїх працях Г. Мешко, О. Мешко та А. Флобойм. Питаннями профілактики та попередження виникнення синдрому професійного виховання в педагогів займаються А. Дербеньова, О. Качур та А. Кунцевська.

Формулювання цілей статті. Мета статті полягає в розкритті причин виникнення синдрому професійного вигорання в педагогів, його ознак та симптомів; визначенні впливу синдрому професійного вигорання на педагогічну діяльність і на безпечну поведінку педагогів, а також винайденні шляхів подолання і попередження професійного вигорання педагогів для підготовки майбутніх педагогів до запобігання синдрому професійного вигорання.

Результати дослідження. Професійне вигорання виникає в результаті внутрішнього накопичення негативних емоцій без відповідної «розрядки» або «звільнення» від них i веде до виснаження емоційно-енергетичних i особистісних ресурсів людини [8]. 3 погляду концепції стресу (Р. Сельє), професійне вигорання - це дистрес, або третя стадія загального адаптаційного синдрому, стадія виснаження.

Професійне вигорання - це реакція організму та психологічної сфери людини, яка виникає внаслідок тривалого впливу стресів середньої інтенсивності, що обумовлені іiі професійною діяльністю; результат некерованого довготривалого стресу; психічний стан, який характеризується виникненням відчуттів емоційної спустошеності та втоми, викликаних професійною діяльністю людини, і поєднує в собі емоційну спустошеність, деперсоналізацію і редукцію професійних досягнень; різновид та передумова професійної деформації особистості. Підсумовуючи викладене, можна зазначити, що синдром вигорання $є$ особистісною деформацією внаслідок емоційно ускладнених або напружених відносин у системі «людина - людина».

Згідно $з$ думкою більшості дослідників, такі поняття, як «втома», «стрес», «нервове виснаження», «професійна деформація», «професійне вигорання» $є$ хоч і спорідненими, але відносно самостійними феноменами. Основна відмінність між вигоранням і втомою полягає в тому, що втомлена людина здатна швидко 
відновитись, а людина 3 синдромом «професійного вигорання» - ні. Перша відмінність між стресом і вигоранням приховується, перш за все, у тривалості процесу: вигорання - це тривалий, «розтягнений» у часі робочий стрес. Другою відмінністю $є$ те, що стрес - це все-таки адаптивний синдром, який мобілізує всі сторони психіки людини, а вигорання - це зрив в адаптації. Третьою відмінністю між стресом і вигоранням $є$ ступінь їхнього розповсюдження. Стрес може відчувати кожен, а вигорання проявляється лише в професійній діяльності. Четвертою відмінністю $є$ те, що стрес не обов'язково може бути причиною вигорання. Відомо, що люди здатні прекрасно працювати в стресових умовах (наприклад, під час війни, стихійних лих, епідемій), якщо вважають, що їхня робота $\epsilon$ важливою та значущою. I останньою відмінністю $\epsilon$ те, що вигорання на відміну від стресу $є$ феноменом незворотним: виникнувши в людини, він продовжує розвиватись, і можна тільки певним чином загальмувати цей процес.

Професійне вигорання виникає під впливом цілком певних зовнішніх і внутрішніх факторів. В. Бойко виділяє такі фактори [2]:

1. Зовнішні фактори, пов'язані з особливостями професійної діяльності: хронічно напружена психоемоційна діяльність; «важкий» контингент, із яким доводиться спілкуватися; дестабілізуюча організація (обстановка) діяльності; важкі умови праці; підвищена відповідальність за виконувані функції й операції; підвищена вимогливість керівництва; неблагополучна психологічна атмосфера професійної діяльності, яка визначається двома основними обставинами: конфліктністю «по вертикалі» (між начальником і підлеглими) і конфліктністю «по горизонталі» (між колегами).

2. Внутрішні фактори, пов'язані 3 індивідуальними особливостями людини: схильність до емоційної ригідності (емоційно стримані люди); інтенсивна інтеріоризація (люди 3 підвищеною); слабка мотивація емоційної віддачі в професійній діяльності (низький рівень емпатії); моральні дефекти і дезорієнтація особистості.

У педагогічній діяльності існує певний набір специфічних стресорів [1]:

- об'єктивна стресогенність педагогічної діяльності: нерегламентоване навантаження; недостатність або неповноцінність засобів відновлення фізичних i психічних ресурсів; висока відповідальність, багато непередбачуваних i неконтрольованих комунікативних ситуацій тощо;

- недостатній рівень соціально-економічної захищеності сучасного вчителя, через що професіоналу доводиться витрачати час і сили на пошук додаткових заробітків;

- загострення внутрішньоособистісних конфліктів педагога: специфічні стандарти самооцінки (ідеал, яким належить бути), підвищена тривожність, величезна кількість «заборон», суперечлива система ціннісних орієнтацій, труднощі у виборі стилю педагогічної взаємодії.

Синдром професійного вигорання розвивається поступово. Згідно 3 К. Маслач (1982), він проходить три стадії [6]: 
1) перша стадія характеризується приглушенням емоцій, згладжуванням гостроти почуттів і свіжості переживань, зникненням позитивних емоцій, появою деякої відстороненості у відносинах із членами сім'ї, виникненням стану тривожності, незадоволеності;

2) друга стадія - виникають непорозуміння з учнями, учитель у колі своїх колег починає зі зневагою говорити про деяких учнів, неприязнь починає поступово проявлятися у присутності учнів, спалахи роздратування;

3) третя стадія - притупляються уявлення про цінності життя, емоційне ставлення до світу стає плоским, людина - небезпечно байдужою до всього.

Існує три аспекти наслідків професійного вигорання [7]:

- зниження самооцінки (відчувають безпорадність і апатію, які з часом можуть перейти в агресію і відчай);

- самотність (переважають об'єкт-об'єктні відносини);

- емоційне виснаження - соматизація (втома, апатія і депресія призводять до серйозних фізичних хвороб - гастриту, мігрені, підвищеного артеріального тиску, синдрому хронічної втоми тощо).

Природно, що в кожної людини професійне вигорання протікає з різним ступенем вияву основних його ознак. Тим не менш всі симптоми, що супроводжують цей процес, можна умовно розділити на три групи [4]:

1. Симптоми, пов'язані з фізичним станом людини:

- підвищена стомлюваність, апатія;

- фізичне нездужання, часті застуди, нудота, головний біль; болі в серці, підвищений або знижений тиск;

- болі в області живота, порушення апетиту і режиму харчування;

- напади задухи, астматичні симптоми;

- збільшення пітливості;

- поколювання за грудиною, м'язові болі;

- порушення сну, безсоння.

2. Симптоми, пов'язані з соціальними відносинами, які проявляються при контакті людини з навколишніми людьми (колегами, клієнтами, друзями, родичами):

- поява тривоги в ситуаціях, де раніше вона не виникала;

- дратівливість і агресивність;

- небажання працювати, перекладання відповідальності;

- відсутність контакту з колегами й учнями, небажання поліпшувати якість роботи;

- формалізм у роботі, стереотипність наказу, опір змінам, активне неприйняття будь-якого творчого початку;

- цинічне ставлення до ідей загальної справи, до своєї роботи; відраза до їжі або переїдання;

- зловживання хімічними речовинами, що змінюють свідомість (алкоголь, куріння, кава, таблетки тощо); 
- втягнення в азартні ігри.

3. Внутрішньоособистісні симптоми - характеризують процеси, що відбуваються всередині людини і зумовлені зміною його ставленням до себе, своїх учинків, думок і почуттів:

- підвищене почуття жалості до себе;

- відчуття власної незатребуваності;

- почуття провини;

- тривога, страх, відчуття загнаності;

- занижена самооцінка;

- відчуття власної пригніченості та безглуздості, песимізм;

- руйнівне самокопання, програвання в голові ситуацій, пов'язаних із сильними негативними емоціями;

- психічне виснаження; сумнів в ефективності роботи.

Професійне вигорання не тільки небезпечно для самих працівників, але й приносить небажані наслідки для організації [3]:

- зниження задоволеності працею, що призводить до збільшення плинності кадрів;

- погіршення соціально-психологічного клімату та збільшення несприятливих фізичних $\mathrm{i}$ емоційних симптомів самопочуття працівників відзначається погіршенням якісних $\mathrm{i}$ кількісних показників роботи та збільшенням витрат на забезпечення здоров’я працівників.

Умовно всі методи гармонізації психофізичного стану людини можна об'єднати в 3 групи [5]: тіло):

1. Фізіологічний рівень регуляції психофізичного стану (вплив на фізичне

- достатньо тривалий і якісний сон (важливо провітрювати приміщення перед сном, дотримуватися режиму сну: засипати i прокидатись в один i той самий час);

- збалансоване, насичене вітамінами і мінералами харчування (особливо протистресовими вважаються мінерал магній i вітамін $\mathrm{E}$, який міститься в кукурудзі, моркві, ожині, горіхах, зернах соняшника, сої);

- достатнє фізичне навантаження, заняття спортом, ранкова гімнастика;

- танці (танцювальні рухи під ритмічну музику сприяють звільненню від негативних емоцій, так само, як і будь-яка хатня робота);

- фітотерапія, гомеопатія (сприяє заспокоєнню чай із м'яти, настоянка 3 кореню валеріани; підвищує життєвий тонус настоянка елеутерококу, женьшеню, родіоли рожевої);

- масаж (допоможе як класичний масаж, так і масаж біологічно активних точок на руках і ногах людини; корисно просто походити босоніж по землі або по насипаним у коробку камінчиках);

- терапія кольором (зелений і синій кольори допомагають заспокоїтись, червоний і жовтий надають енергію та бадьорість); 
- ароматерапія (запахи апельсину, бергамоту діють на нервову систему збуджуючи, з'являється відчуття приливу сил; запахи лаванди, анісу, шавлії діють заспокійливо, допомагають зняти нервове напруження);

- терапія мінералами - дихальні вправи (заспокійливе з подовженим видихом дихання зменшує надлишкове збудження i нервове напруження; мобілізуюче дихання 3 збільшеним вдихом допомагає подолати в'ялість, сонливість);

- баня і водні процедури (контрастний душ перед сном допоможе зняти втому дня, а зранку додасть бадьорості).

2. Емоційно-вольова регуляція психофізичного стану (вплив на емоційний стан):

- гумор (сміх позитивно впливає на імунну систему, активізуючи Тлімфоцити крові; у відповідь на вашу усмішку організм продукуватиме бажані гормони радості; гумор чудово «перезаряджає» негатив);

- музика (найкраще сприяе гармонізації психоемоційного стану прослуховування класичної музики, рок теж буває корисним, він допомагає вивільнитись від негативних емоцій);

- спілкування з сім'єю, друзями;

- заняття улюбленою справою, хобі (книжки, фільми, в'язання, садівництво, рибальство, туризм...);

- спілкування з природою (природа завжди дає людині відчуття приливу сил, відновлення енергії);

- спілкування з тваринами;

- медитації, візуалізації (існують цілеспрямовані, задані на певну тему візуалізації - уявно побувати у квітучому саду, відвідати улюблений куточок природи тощо);

- аутотренінги (самонавіювання).

3. Ціннісно-смисловий рівень регуляції психофізичного стану (вплив на думки, зміна світогляду). Образа, злість, невдоволення, критика себе та інших все це найшкідливіші для нашого організму емоції. Наш мозок викидає гормони стресу на будь-які подразники, що загрожують нашому спокою. При цьому йому зовсім байдуже, реальні вони чи вигадані. Тому і на надуману проблему організм відреагує, як на справжню. Отже, важливо навчитись контролювати свої думки i емоції і навчитися сприймати будь-які події з позитивного боку.

Фактори, що сприяють створенню позитивного психологічного клімату в учнівському та педагогічному колективах [1].

- педагогічна емпатія - осмислення, відтворення та розуміння психічних станів учнів учителем;

- педагогічне спілкування - установлення контакту з учнями, професійний вплив педагога на учнів, спрямований на оптимізацію навчально-виховної діяльності та особистісних стосунків між ними; 
- педагогічний такт - найважливіший компонент професійної майстерності вчителя, що грунтується на почутті міри впливу на учнів i встановленні з ними ділових та емоційних стосунків;

- педагогічна творчість - оригінальне й ефективне вирішення вчителем навчально-виховних завдань, збагачення теорії та практики виховання i навчання.

Висновки $з$ дослідження та перспективи подальших розвідок у цьому напрямі. Отже, професійне вигорання - це синдром, що розвивається на фоні хронічного стресу і веде до виснаження емоційно-енергетичних і особистісних ресурсів педагога. На думку всіх авторів, які досліджують синдром професійного вигорання, розвиток його симптоматики має стадіальний характер, а загальна схема розвитку синдрому професійного вигорання виглядає так: спочатку спостерігаються значні енергетичні витрати як наслідок екстремально високої позитивної установки на виконання професійної діяльності, потім з'являється почуття втоми i, нарешті, розчарування, зниження інтересу до своєї роботи.

Профілактика професійного вигорання починається з розпізнавання i розуміння суті проблеми. Усі методи гармонізації психофізичного стану людини можна об'єднати в 3 групи: вплив на фізичне тіло, вплив на емоційний стан, вплив на думки, зміна світогляду. Основними найрозповсюдженішими способами попередження професійного вигорання $є$ такі: по-перше, необхідно професійно самовизначитись (правильний вибір професії); по-друге, людина має для себе визначити цілі та терміни їх досягнення (професійний таймменеджмент); по-третє, треба прагнути до нормальних санітарно-гігієнічних умов праці та уникати понаднормовості.

Майбутні педагоги мають обов'язково володіти інформацією про синдром професійного вигорання як один із ризиків педагогічної діяльності, знати його симптоми та шляхи попередження для того, щоб правильно скласти свою програму професійного довголіття.

\section{СПИСОК ВИКОРИСТАНИХ ДЖЕРЕЛ}

1. Дербеньова, А. Г. і Кунцевська, А. В. (2010). Адміністратору школи. Тренінги 3 розвитку комунікативності вчителів. Харків, Україна: Вид. група “Основа".

2. Бойко, В. В. Синдром эмоционального выгорания в профессиональном общении. СПб., Россия.

3. Водопьянова, Н. Е. и Старченкова, Е. С. (2009). Синдром выгорания: диагностика и профилактика. СПб., Россия: Питер.

здоров'я

4. Волкова, О. Б. (б.д.). Синдром професійного вигорання: як зберегти психоемоційне https://ru.osvita.ua/school/lessons_summary/psychology/38435/

$\begin{array}{lll}\text { Osvita.ua. } & \text { Взято }\end{array}$

5. Качур, О. (2010). Профілактика професійного вигорання у закладах освіти. Психолог, $40(424), 3-7$. Генеза.

6. Маслач, К. (2000). Професійне вигоряння: як люди справляються. Київ, Україна: 
7. Мешко, O. I. (2003). Синдром «емоційного згорання» вчителя у контексті професійної діяльності шкільного психолога. Психолого-педагогічні засади професійного становлення особистості психолога. Ч.3, с. 104-112.Тернопіль, Україна.

8. Флобойм, А. В. (2011). Професійні захворювання та їхня профілактика. Київ, Україна: Шкільний світ.

\title{
ПОДГОТОВКА БУДУЩИХ ПЕДАГОГОВ К ПРЕДОТВРАЩЕНИЮ СИНДРОМА ПРОФЕССИОНАЛЬНОГО ВЫГОРАНИЯ
}

\author{
Марина Бутырина \\ кандидат педагогических наук, доцент, доцент кафедры общетехнических \\ дисциплин, безопасности жизнедеятельности и автодела, \\ ГВУЗ «Донбасский государственный педагогический университет», \\ г. Славянск, Украина \\ ORCID ID 0000-0002-5048-5187 \\ butyrina_mv@ukr.net \\ Владимир Перейма \\ кандидат педагогических наук, доцент, доцент кафедры общетехнических \\ дисциплин, безопасности жизнедеятельности и автодела, \\ ГВУЗ «Донбасский государственный педагогический университет», \\ г. Славянск, Украина \\ ORCID ID 0000-0003-0403-9730 \\ pereima_v@ukr.net
}

Аннотация. В статье раскрыты причины возникновения синдрома профессионального выгорания у педагогов, объединенные во внешние факторы (связанные с особенностями профессиональной деятельности) и внутренние факторы (связанные с индивидуальными особенностями человека); подано признаки профессионального выгорания, развивающиеся в течение трех стадий: сначала снижение самооценки, впоследствии одиночество и, как следствие, соматические расстройства организма; исследованы последствия профессионального выгорания: симптомы, связанные с физическим состоянием человека, с социальными отношениями и внутриличностные симптомы; определено его влияние на педагогическую деятельность и на безопасном поведении педагогов; выделено пути преодоления профессионального выгорания педагогов, объединенные в три группы: воздействие на физическое тело, влияние на эмоциональное состояние, влияние на мысли и мировосприятие; даны рекомендации относительно подготовки будущих педагогов к предотвращению синдрома профессионального выгорания педагогов.

Ключевые слова: синдром профессионального выгорания, педагогическая деятельность, подготовка будущих педагогов, стрессогенность, внешние факторы синдрома профессионального выгорания, внутренние факторы синдрома профессионального выгорания.

\section{FUTURE TEACHERS TRAINING TO THE PREVENTION OF OCCUPATIONAL BURNOUT SYNDROME}

\author{
Maryna Butyrina
}

Candidate of Pedagogical Sciences, Associate Professor of 


\author{
Department of General Technical Disciplines, Safety \\ of Vital Activity and Automotive Engineering \\ SHEE "Donbas State Pedagogical University" \\ Sloviansk, Ukraine \\ ORCID ID 0000-0002-5048-5187 \\ butyrinamv@ukr.net \\ Volodymyr Pereima \\ Candidate of Pedagogical Sciences, Associate Professor of \\ Department of General Technical Disciplines, Safety \\ of Vital Activity and Automotive Engineering \\ SHEE "Donbas State Pedagogical University" \\ Sloviansk, Ukraine \\ ORCID ID 0000-0003-0403-9730 \\ pereima_v@ukr.net
}

Abstract. The issue of the article is relevant for today due to the increased stress-related pedagogical activity associated with the reform of the education in Ukraine, filling it with new content, as well as changing the role of the teacher in the educational process and making high demands to the teacher's personality (the need for constant self-development, skills and abilities), to his mental state, especially in conditions of large information overload and tension caused by extrahour, paper and monotonous work.

The problem of teachers' occupational burnout is studied in the works by H. Meshko, O. Meschko and A. Flaubom, and the issues of preventing the emergence of the syndrome while training teachers are studied by A. Derbeneva, A. Kachur and A. Kuntsevska.

The purpose of the article is to highlight the main symptoms of the teacher's occupational burnout, to investigate factors leading to burnout and to find ways to prevent the emergence of teachers' occupational burnout symptom, which is vital for future educators training for safe professional activities.

The article reveals the factors contributing to the emergence of the syndrome of teachers' occupational burnout: external factors (associated with the characteristics of professional activity: chronically intense psycho-emotional activity, "heavy" contingent with which we have to communicate, destabilizing organization (situation), increased responsibility for the lives of children and controversial issues in assessing their knowledge, increased demands for leadership, unfavorable psychological atmosphere in the team) and internal factors (related to the individual characteristics of a person: the propensity to emotional rigidity, lack of motivation for professional activity, caused by the lack or poor emotional impact and low student performance). Also, the article reveals the signs of occupational burnout, developing at three stages: a decline in self-esteem, loneliness and, as a result, somatic disorders of the body. The consequences of occupational burnout are manifested in symptoms that are classified into three groups: symptoms associated with the person's physical condition, with social relations and intrapersonal symptoms, which affects the quality of pedagogical activity and the safety of the organization of educational process for the educators.

The article outlines ways of overcoming teachers' occupational burnout, united in three groups: impact on the physical body, influence on the emotional state, influence on thoughts and perception of the world; recommendations are given regarding the future teachers' training to prevent the syndrome of teachers' occupational burnout.

Key words: occupational burnout syndrome; pedagogical activity; future teachers' training, stressogenicity; external factors of the syndrome of occupational burnout; internal factors of the syndrome of occupational burnout. 
Підготовка майбутніх педагогів до запобігання синдрому професійного вигорання

\section{REFERENCES (TRANSLATED AND TRANSLITERATED)}

1.Derbenova, A. H. \& Kuntsevska, A. V. (2010). To school administrator. Trainings for developing teachers' communicativity. Kharkiv, Ukraine: Vyd. hrupa "Osnova". Russia.

2.Boiko, V. V. (1999). Syndrome of emotional burnout in professional communication. SPb.,

3.Vodopianova, N. E. \& Starchenkova, E. S. (2009). Syndrome of burnout: diagnostics and prophylactics. SPb., Russia: Piter.

4.Volkova, O. B. Syndrome of occupational burnout: how to save teachers' psycho-emotional health. Osvita.ua. Retrieved from https://ru.osvita.ua/school/lessons_summary/psychology/38435/

5.Kachur, O. (2010). Prophylactics of occupational burnout in educational establishments. Psykholoh, 40 (424), 3-7.

6.Maslach, K. (2000). Occupational burnout: how people deal with. Kyiv, Ukraine: Heneza.

7.Meshko, O. I. \& Meshko, H. M. (2003). Syndrome of teachers' "emotional burnout" in the context of school psychologist's professional diagnostics. Psykholoho-pedahohichni zasady profesiinoho stanovlennia osobystosti psykholoha. Part 3, pp. 104-112. Ternopil, Ukraine.

8. Floboim, A. V. (2011). Occupational diseases and their prophylactics. Kyiv, Ukraine: Shkilnyi svit.

Матеріали надійшли до редакції 14.11.2018 р. 